\title{
Register-Based Family and Household Statistics
}

\author{
OLE KAYSEN PETERSEN
}

\section{Introduction}

This paper describes a family and household module as regards both technical aspects and contents.

The quality of the information comprised by the module is constantly being improved, and it is also possible to supplement and even extend the register by including data from other population registers.

The module is of recent date and there has as yet therefore been no opportunity to use the module in analyses of family and/or household structures. The conclusion of the paper will, however, give a couple of examples of the possible uses to which the module may be put, first and foremost in connection with family statistics.

\section{Family statistics}

Danmarks Statistik has conducted a survey of families as of 1st January every year since 1974. Until 1 January 1978 it was limited to a group of persons selected by date of birth. In 1978 a reform of the Central Population Register was carried out, making the improvement and expansion of the family module possible.

In 1981 the establishment of a new family and household module was completed, and for the first time household statistics could now also be compiled using registers. Starting with 1 January 1980, the new family and household module can be used for the entire population, and it has been established on the basis of data from Danmarks Statistik's population register, which in turn is based on information from the Central Population Register.

\section{Use of the family and household module}

The family and household module is a classification module. The characteristic of this type of module is that it always contains data at the level of the most elementary unit - the level of the person or address. The information can therefore be used as basic data within the various areas of statistics. In several areas, the statistics at the level of the family and household are an indispensable supplement to the statistics at the level of the person. The module is for example used for income and occupation statistics, statistics concerning the Social Assistance Act, and dwelling statistics, in addition to being used in the Population and Housing Census 1981 and the education statistics. The module will similarly be used in connection with household forecasts and for an extension of the demographic statistics.

\section{Family and household concepts}

The identification of families and households is based on the size and composition of the population as of 1 January, at the level of the person. Each 
person's family and household characteristics are established in accordance with fixed definitions.

A distinction is made in the module between 3 concepts, namely 2 family concepts and 1 household concept. The family concepts comprise a so-called family nucleus, defined as a person or group of persons 1) living at the same address, and 2) who are related in specific ways, for instance a married couple with/without children or a single person with/without children. The family concepts comprise several family classifications corresponding to various definitions of family characteristics. Family type A is the most clearly defined as it is based on unequivocal legal definitions. The distinction is made in family type A between cohabiting married couples and single persons. Families with children living at the same address only include children under the age of 18 . In comparison with this traditional family definition, family type B represents a broadening of the definition to take into account families consisting of couples in consensual union with joint children and any separate children. In this concept, children living at the same address as their parents are included up to the age of 26.

The household concept comprises all persons living at the same address irrespective of family relationship. This implies that one household may consist of several families.

\section{Family identification}

The identification of a "family nucleus" is based on the so-calied reference numbers which are identical to the person numbers. Each reference number refers to one other person, either mother, father or spouse. A total of 4 person numbers are registered for each person, including his own person number. These reference numbers are based on legally defined family characteristics and can never be erased. Figure $1 \mathrm{~A}$ demonstrates the way in which a married couple can be matched with a joint child and a separate child respectively. Figure 1B shows the linking of a couple in consensual union with two joint children (the family B concept).

Fig u r e $1 \mathrm{~A}$

Cross-reference numbers

Person Person number Person number Person number

number of mother of father spouse

$\begin{array}{llll}\text { Father } & \\ \text { Mother } & \text { Child } & \end{array}$

F i g u r 1B

Cross-reference numbers

\begin{tabular}{cccc}
$\begin{array}{c}\text { Person } \\
\text { number }\end{array}$ & $\begin{array}{c}\text { Person number } \\
\text { of mother }\end{array}$ & $\begin{array}{c}\text { Person number } \\
\text { of father }\end{array}$ & $\begin{array}{c}\text { Person number } \\
\text { of spouse }\end{array}$ \\
\hline
\end{tabular}

Father
Mother
Child
Child




\section{Family number}

Each family can be identified by a number, which is the person number of a so-called »reference person». For cohabiting married couples and couples living in consensual union with joint children, the reference person is always the woman. The woman has been chosen as the reference person because a better cross-reference has been ascertained between mother and child than between father and child. For other family nuclei, that is, all families with the exception of those just mentioned, the reference person is the oldest person in the nucleus.

\section{Family classification}

The use of cross-reference numbers makes it possible in theory to identify several different family types, using the family B concept:

- a cohabiting couple, legally married, with or without (joint or separate) children under 26 years old living at the same address.

- a cohabiting couple, living in consensual union, with joint children under 26 years old living at the same address plus any separate children in addition to the joint children.

- a single married person (but separated from the spouse), divorcee or widow/widower with or without children under 26 years old living at the same address.

- a never-married person aged 26 years old or more with or without children living at the same address.

- a never-married person aged under 26 years old, living at a different address from that of the parents, and without children living at the same address.

It should be noted that a person is not included as a child in a family if he or she is married, divorced or a widow/widower. In such cases, the person is included as a married person, living in a consensual union, divorced or as a single person in another separate family. A summary of the family types included in the module is given in Appendix 1 (see p. 84).

Following a reform of the Central Population Register in 1978 possibilities arose for improving and extending the family module.

Until the reform of the Central Population Register in 1978, only children under 18 years old could be included in the family identification of the module. The reason for this was that the cross-references from child to parent were automatically deleted as soon as the child reached 18 years of age. This deletion no longer takes place and it is thus possible to include children irrespective of age living at the same address as their parents. In practice however the limit is set at 26 years, so that only children under this age are included. Table 1 shows the significance or this change in age limit for children living at the same address as their parents.

The table shows that, after the change in age limit came into effect, 212,384 persons are now included as children living at the same address as their parents. Had the age limit of 18 years been continued, these persons would have been considered as single persons and thus as separate families. Furthermore, it can be seen that the number of families with children living at the same address has increased by 98,814 families.

Part of the reason for changing the age limit was the possibility of tracing the progress of persons receiving education, in relation to their social/family background, even though many children between the ages of 18 and 25 and living at home are financially independent and should thus in certain respects be regarded as separate families. 
T a b l e 1.

\begin{tabular}{lrrrrr}
\hline $\begin{array}{l}\text { Age of } \\
\text { youngest } \\
\text { child }\end{array}$ & \multicolumn{3}{c}{ Families with children } & & $\begin{array}{c}\text { Number of } \\
\text { children, } \\
\text { total }\end{array}$ \\
\cline { 2 - 5 } & $\begin{array}{c}\text { Single } \\
\text { persons }\end{array}$ & $\begin{array}{l}\text { Married } \\
\text { couples }\end{array}$ & $\begin{array}{l}\text { Couples living } \\
\text { in consensual } \\
\text { union }\end{array}$ & Total & \\
\hline $0-17$ years & 138995 & 538954 & 38721 & 716670 & 1220677 \\
$18-25$ years & 23065 & 75715 & 34 & 98814 & 212384 \\
Total & $\mathbf{1 6 2 0 6 0}$ & $\mathbf{6 1 4 6 6 9}$ & $\mathbf{3 8 7 5 5}$ & $\mathbf{8 1 5 4 8 4}$ & $\mathbf{1 4 3 3 0 6 1}$ \\
\hline
\end{tabular}

Until now, it has been impossible to identify couples living in a consensual union, because previously there was only a reference from the child to either the mother or the father. In most cases there is now a reference from the child to both the mother and the father. This possibility is utilized to identify family types comprising couples living in consensual union with joint children. It is important to note that this only applies to couples living in consensual union with joint children (plus any separate children), and not to couples with separate children only, or couples without children. It is not possible to include all couples living in consensual union because the identification of this family type is based on the cross-reference from child to parent. There are no references between the parents as they are not legally married. Thus, when there is a cross-reference from a child to both the mother and the father living at the same address, and the parents are not registered as being married to each other, a couple living in consensual union with joint children can be identified. In all other situations, a family consisting of single persons with or without children would be identified.

\section{Household identification}

Identification of a household is, as mentioned earlier, based on an enumeration of all the persons living at the same address, irrespective of family relationship. At the same time it is possible to count the number of families living at the same address as well as refer them to certain family types. It is thus possible to characterize each household on the basis of its composition as regards persons and families. It must be emphasized that no distinction can be made at the moment between private and institutional households. This fact is important in the interpretation of the concept »multi-family households" consisting of many persons. There are plans to carry out a linking of the family and household register with the register of institutional households in order to make a closer examination of the large households. An outline of the household types contained in the model is given in Appendix 2 (see pp. 85 and 86).

\section{Problems with regard to quality}

Data from the Central Population Register are generally considered to be of a very high quality. A correct identification of families and households makes heavy demands on a precise indication in the Central Population Register of each person's address, marital status and family characteristics. These requirements cannot always be said to be fulfilled, and the consequences will now be discussed. As family and household identifications are partly based on address data, 
incomplete or inaccurate address designations give rise to several different types of mistake. A cohabiting married couple will thus appear as two single persons if the address of one of the spouses is incorrectly entered in the Central Population Register (the house number for example may have been omitted). Incorrect address designations may also result in too many persons being placed in the same household, that is, at the same address. The number of incorrect or inaccurate address designations has however been reduced considerably in recent years, following a comprehensive revision in connection with the establishment of the Central Register of Buildings and Dwellings (BBR).

As a precise address designation is crucial for correct family identification, a short account now follows of how addresses are kept up to date. A person changing address has a duty to report this. A change of address form must be completed and sent to the local population register in the municipality of the new address. The change of address is then reported by the local to the central population register. However, changes of address are occasionally not registered. The close contact which exists today between citizen and public administration, either in connection with the labor market or social welfare system, means that failure to report changes of address is not a serious problem although there may be a certain delay between a change of address and its notification to the authorities.

The identification of the family type "couples living in consensual union with joint children" is incomplete, the total number of this family type being underestimated. This is evident from the omnibus surveys. ${ }^{1}$ The reason for the discrepancy is first and foremost the fact that cross-references between a child and its father living in consensual union with the mother have not been established throughout the Central Population Register.

The missing cross-references are, however, constantly being added and a comparison of surveys in the period 1980-1984 proves this. According to these surveys, the number of persons living in consensual union has tripled over the period. This does not, of course, represent a real increase alone, but is also to a considerable extent due to the tracing of missing cross-reference numbers in the Central Population Register. It is to be expected that these corrections, and thus better quality, will continue in future years.

The missing data clearly constitute a slaw in the register, as, were they available, it would be possible to count the number of couples living in consensual union with separate children or without children at all. If the data in the household register are used, a closer approximation could be reached. A large proportion of this »hidden» family type can be found amongst household types consisting of two single persons of opposite sex with or without children. In all probability, a number of these single persons are only sharing the same address rather than living in consensual union and a closer delimitation would be necessary in order to resolve the problem. By classifying the persons in this household type by age, and eliminating those who are closely related, an even closer estimated could be reached.

\section{Use of other registers}

As mentioned earlier, the family and household module is based solely on data from the Central Population Register. In this way, it is certain that the material is always up-to-date and of uniform time-reference, and conforms with parts of the population statistics. As regards the family and household module, data from other registers can profitably be used to improve the module.

1 Sample surveys carried out jointly by Danmarks Statistik and the Social Research Institute. 
The problems of identifying the number of persons living in consensual union with separate children could be solved by linking the family and household module with the statistical register of family allowances. This register contains data on persons receiving either ordinary or increased family allowance, the latter only being paid to lone breadwinners. If the household module were linked with the statistical register of family allowances, with special reference to the household type "two single persons of opposite sex", the households in which one or more persons receive ordinary family allowance could be classified as persons living in consensual union with separate children. A linking of the module and the register has recently been carried out and agrees well with the results of the omnibus surveys (Table 2).

T a b l e 2 .

Omnibus survey 1982

Household module/

register of family allowances

Couples living in consensual unions with joint children

55.000

37.000

Couples living in consensual union with separate children only

25.000

24.500

The results prove that it is possible to single out yet another family type.

The linking of the module and the statistical register of family allowances will lead to a careful consideration of the extent to which data from the register should be used for the identification of families and households.

\section{Use of the family and household module in population statistics}

As mentioned in the introduction, the establishment of the module has only recently been completed, and as long as the quality of the data continues to be improved, use of the module for research purposes such as cohort studies must be postponed.

The following examples will show how the module can be used to supplement the divorce statistics, as well as how it can be used to measure the increase or decrease in the population of families.

\section{Divorces involving children}

The basis for the divorce statistics is Danmarks Statistik's register of population statistics, which receives data on every divorcee resident in Denmark from the Central Population Register.

These data are electronically processed with the purpose of combining information about both partners in every divorce case. The data in the Central Population Register refer only to persons who until the divorce were legally married to each other, and can therefore not be used to describe any family of which the two divorcees may now be members. The number of children of dissolved marriages is not known therefore, although it could be estimated.

As the Central Population Register no longer includes the date of separation, the general divorce statistics use the period from the date of marriage to the date of divorce as an expression of the duration of the marriage. This definition is 
rather unfortunate, as the actual duration of the marriage is often more relevant than the legal duration.

Use of data from the family module makes it possible to analyze divorces by the number of children at the time when the marriage was actually dissolved, as well as to estimate the actual duration of dissolved marriages.

Methodological problems arise, however, if a particular event is matched with background data which do not have the same time reference. Additionally, as we are not interested in the legal duration, the date of the divorce cannot be used.

The problem has been solved as follows. Every registered divorce in a particular year is matched with the register of families, taking 1st January of the same year as the time reference. If the divorcees have not lived at the same address at the start of the year of divorce, the register of families from the previous year is consulted. The date at which a joint address is noted will then be regarded as the date when the marriage was dissolved. The actual duration of the marriage can therefore be estimated (with a maximum discrepancy of 1 year) as the period from the date of marriage to the date when the spouses no longer lived together at the same address. Table 3 shows the results of a linking of the register of divorces 1982 with family modules for the last 5 years. Of an annual divorce population numbering 14,600 , it was possible in $89 \%$ of cases to find family data referring to a date immediately prior to the dissolution of the family. The remaining $11 \%$ comprises divorces with a period of separation of more than 5 years and marriages contracted after one reference date but dissolved before the next. Experience shows that this figure is very low - a total of 60 couples in 1982.

Appendix 3 (see pp. 86 and 87) shows three examples of divorce tables containing data taken from the family module.

\section{Changes in family structure}

The family/household module can act as a starting point for the measurement of changes in the family structure over a period of time, a minimum of 1 year. As every person is identifiable by both person number and family number, it is possible to trace any changed family characteristics of each person, and similarly, a family can be studied with reference to changes in the number of its members. In theory it is possible to study the change in a family's/person's circumstances as well as to measure the increase and decrease in the size of a family.

$\mathrm{T}$ a ble 3 .

Date of most recent joint

Divorces 1982

address

$\begin{array}{lr}\text { 1. } 1.1982 & 2886 \\ \text { 1. 1. } 1981 & 5567 \\ \text { 1. 1. } 1980 & 3191 \\ \text { 1. 1. } 1979 & 931 \\ \text { 1. } 1.1978 & 453\end{array}$

Spouse resident in 
Changes in the population of families, defined as the total number of families throughout the year, are due to increases and decreases, thus altering the entire family pattern (percentage of each family type). Factors of increase are:

- immigration

- a child living at the same address as the parents moves

- a child living at the same addres as the parents reaches 26 years of age

- a child living at the same address as the parents has a child of its own

- a marriage or couple living in consensual union with joint children is dissolved, that is, the partners no longer live together at the same address

In theory, increase can also be due to birth, after which the child leaves its natural parents and is placed in the care of foster parents. Factors of decrease are:

- death of a single person without children

- emigration of a single person with/without children (all family members emigrate)

- emigration of a married couple with/without children or a couple living in consensual union with joint children (all family members emigrate)

- two single persons marry and start living at the same address

- two single persons with joint children start living together at the same address

In practice however a complete study of such changes makes great demands on data organization and resources.

If the alternative structures of a family over a period of time are considered from the point of view of the family type classification of the module, it appears that there are two types of movement, a horizontal and a vertical. The horizontal movement primarily indicates a movement between two main groups, e.g. from the group "a single person without children» to "a single person with children». A vertical movement can be described as a change in circumstances within the same main group. Figure 2 (p. 82) illustrates the two types of movement for a family nucleus comprising a single adult with children.

Figure 2 shows that such a family nucleus can, from one point in time to another, change to one of five alternative structures. It must be emphasized that this example is not definitive, but only serves to illustrate the complexity of an analysis of family circumstances over a period of time. It is, of course, possible, to specify the individual family types further by including other family characteristics such as parents' age, number and sex of children, etc. This certainly emphasizes the many aspects of the module.

\section{Bornholm - an example}

Finally, an example will be given, showing how the family module can be used to illustrate the changes in the number of marriages on Bornholm. A marriage is here defined as two spouses living at the same address. The number of marriages on a specific date is the result of enumeration of the horizontal lines intersecting the vertical axis. The net change in the number of marriages is found by comparing the statistics from two reference dates. As a result of this method of registration, it is not possible to register marriages contracted and dissolved within the observation period (see Figure 3, p. 82).

A wedding and a divorce lead typically to the contraction and dissolving of a marriage respectively, in legal terms. In addition, a marriage dissolves on the death of one of the spouses, while emigration of a spouse does not necessarily dissolve the marriage although in practice this is the result in many cases. When the family module is being used, the importance of the following must be stressed:

- that the address designation is crucial to family identification

- that the module does not include data on changes 
Figure 2 .

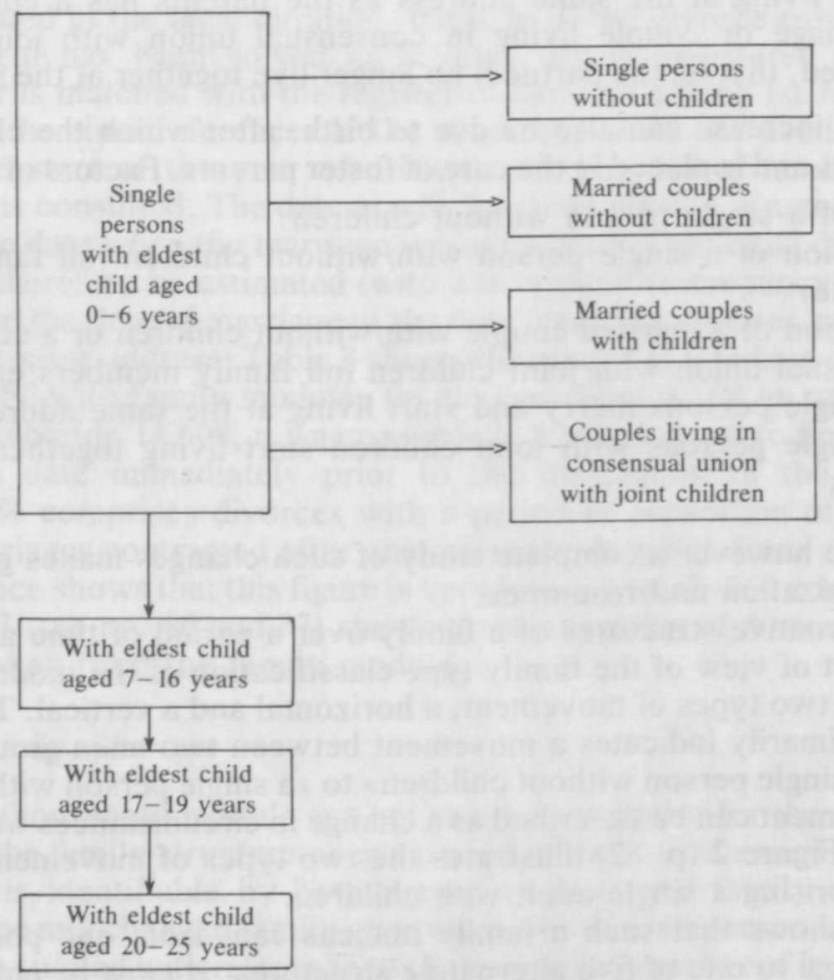

Fig u re 3 .

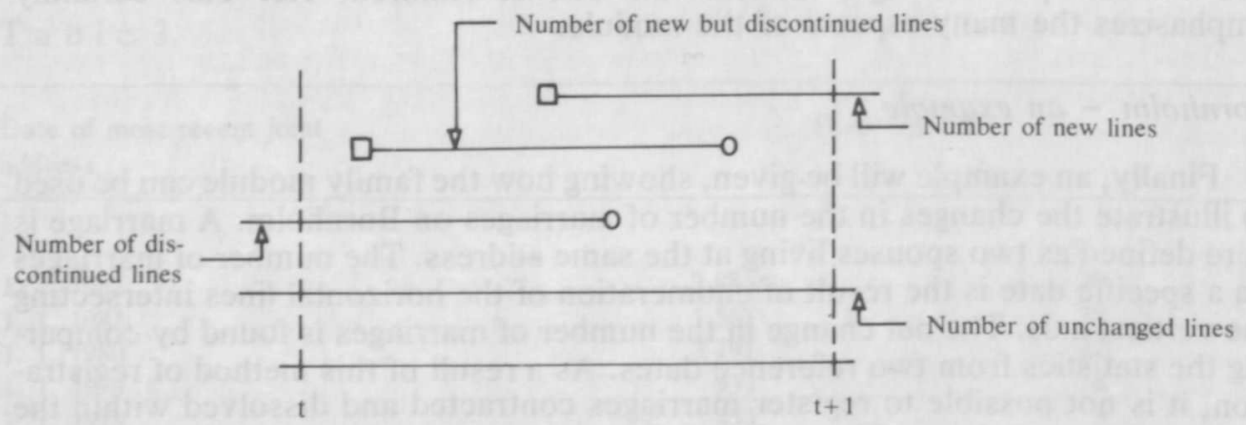

This means that an increase can be interpreted as two people who have married and live at the same address, or as two spouses who have been separated for a period and now live at the same address again.

A decrease means that the spouses no longer live at the same address, either as a result of a change of address, emigration or death. 
10.676 marriages were registered using the family module on 1st January 1983 on Bornholm. The figure on 1st January 1984 was 10,612 , i.e. a slight decrease in the number of marriages.

A linking of the two registers at given points of time revealed that 10,237 marriages remained unchanged from 1983 to 1984 . There have thus been 375 new marriages while 439 were dissolved in 1983.

Data concerning each person's family characteristics on 1st January 1984 were recorded for marriages dissolved during 1983, and likewise for new marriages on 1st January 1983.

After linking the two registers it has been possible to discover the family types from which the increase in the number of marriages derives. Furthermore, the "decrease population" now appears as an increase in the number of other family types. Figure 4 illustrates the result, and will be briefly commented upon.

Fig u re 4

\begin{tabular}{|c|c|c|}
\hline & $\begin{array}{l}\text { Married couples moving to the } \\
\text { region from the rest of } \\
\text { Denmark/foreign country }\end{array}$ & Number of persons \\
\hline $\begin{array}{l}\text { MARRIAGE 1) } \\
\text { IN } 1983 \\
\text { OF PERSONS } \\
\text { WHO: }\end{array}$ & $\begin{array}{l}\text { Migrated to the region in } 1983 \\
\text { Living in consensual union } \\
\text { Child living at the same address } \\
\text { as the parents } \\
\text { Single person without children } \\
\text { Single person with children } \\
\text { Spouse from previous marriage }\end{array}$ & $\begin{array}{r}29 \\
97 \\
19 \\
337 \\
94 \\
2\end{array}$ \\
\hline
\end{tabular}

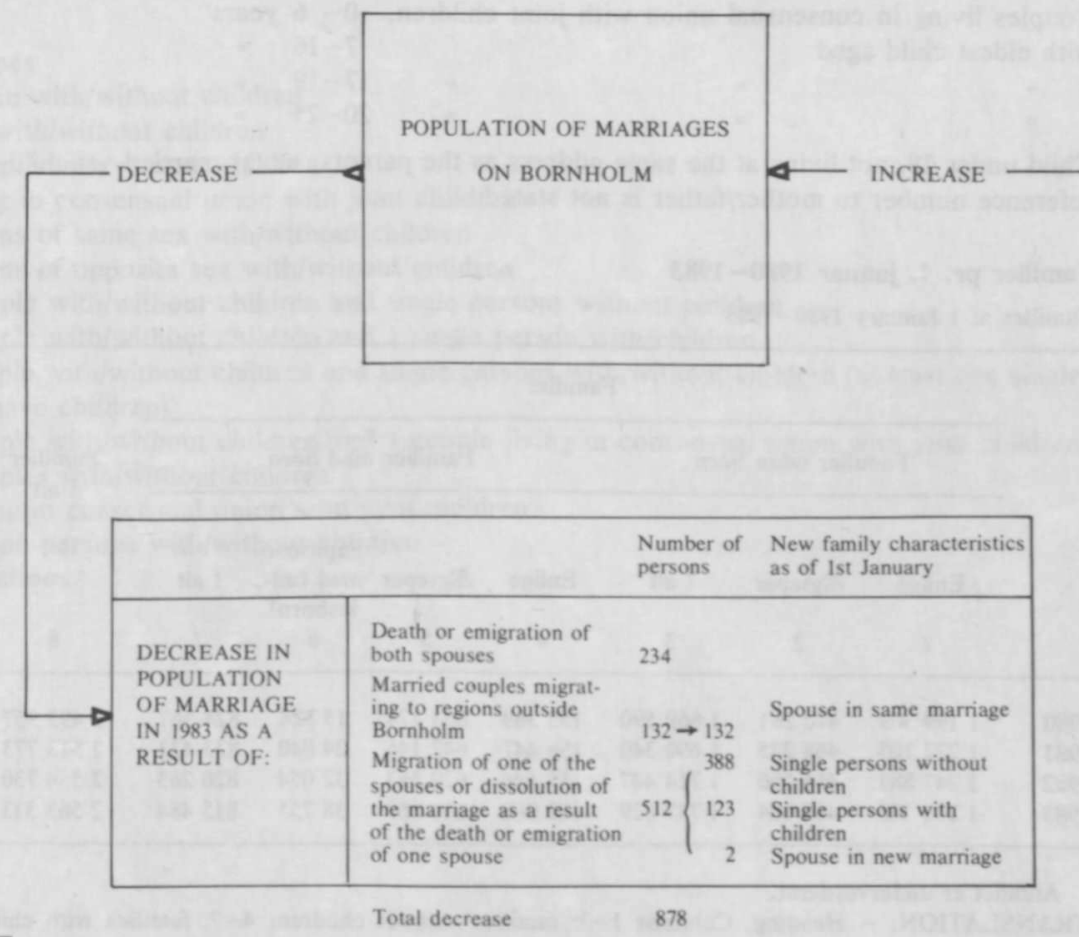

1) A marriage is here defined as the contraction of marriage between 2 non-married persons or two spouses moving to the same address again. 
As this is a regional survey, it is necessary to include migrations into and out of the area, which, of course, complicates the statistics for each particular family type.

The regional aspect can be extended to include an analysis of increases and decreases by areas, outside and inside the region respectively, and similarly, an increase can be analyzed by using the combination of family types which characterized the partners immediately before the contraction of marriage.

As is evident, there are several potential ways of approaching an analysis of family characteristics. However, the purpose of the analysis must be specified in advance, as the planning of the project places great demands on the organization of the data.

\section{A p pe n d i 1 .}

Family types

Single persons without children

Married couples without children

Single persons with children, with eldest child aged $0-6$ years

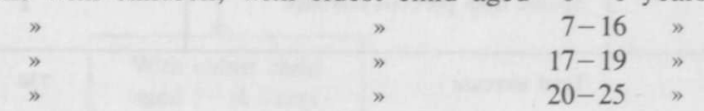

Married couples with children, with eldest child aged $0-6$ years

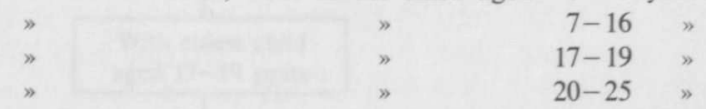

Couples living in consensual union with joint children, $0-6$ years with eldest child aged

$7-16$
$17-19$
$20-25$

Child under 18 , not living at the same address as the parents, never married, or child whose crossreference number to mother/father is not stated.

Familier pr. 1. januar 1980-1983

Families at 1 January 1980-1983

\begin{tabular}{|c|c|c|c|c|c|c|c|c|c|}
\hline & \multicolumn{7}{|c|}{ Familier } & \multirow{4}{*}{$\begin{array}{l}\text { Familier } \\
\text { i alt }\end{array}$} & \multirow{3}{*}{$\begin{array}{c}\text { Antal } \\
\text { personer } \\
\text { i alt }\end{array}$} \\
\hline & \multicolumn{3}{|c|}{ Familier uden børn } & \multicolumn{4}{|c|}{ Familier med børn } & & \\
\hline & Enlige & Egtepar & I alt & Enlige & Agtepar & $\begin{array}{l}\text { Papirløse } \\
\text { med fæl- } \\
\text { lesbørn }{ }^{1}\end{array}$ & I alt & & \\
\hline & 1 & 2 & 3 & 4 & 5 & 6 & 7 & & 9 \\
\hline 1980 & 1199309 & 470281 & 1669590 & 155369 & 653174 & 15824 & 824367 & 2493957 & 5122065 \\
\hline 1981 & 1222105 & 468235 & 1690340 & 156447 & $642 \quad 146$ & 24840 & 823433 & 2513773 & 5123989 \\
\hline 1982 & 1247881 & 466566 & 1714447 & 158646 & 629583 & 32054 & 820283 & 2534730 & 5119155 \\
\hline 1983 & $1281 \quad 165$ & 466664 & 1747829 & 162060 & 614669 & 38755 & 815484 & 2563313 & 5116464 \\
\hline
\end{tabular}

1 Antallet er undervurderet.

TRANSLATION. - Heading, Columns 1-3: families without children; 4-7: families with children; 1 and 4 : single persons; 2 and 5: married couples; 6: couples living in consensual unions, with joint children; 3 and 7 : total; 8: total number of families; 9 : total number of persons. 
Familier pr. 1. januar 1983 fordelt efter antal personer

Families at 1 January 1983 , by family size

\begin{tabular}{|c|c|c|c|c|c|c|c|c|c|}
\hline \multirow{4}{*}{$\begin{array}{c}\text { Antal } \\
\text { perso- } \\
\text { ner i } \\
\text { fami- } \\
\text { lien }\end{array}$} & \multicolumn{7}{|c|}{ Familier } & \multirow{4}{*}{$\begin{array}{l}\text { Familier } \\
\mathrm{i} \text { alt }\end{array}$} & \multirow{3}{*}{$\begin{array}{c}\text { Antal } \\
\text { personer } \\
\text { i alt }\end{array}$} \\
\hline & \multicolumn{3}{|c|}{ Familier uden børn } & \multicolumn{4}{|c|}{ Familier med børn } & & \\
\hline & Enlige & Ægtepar & I alt & Enlige & Ægtepar & $\begin{array}{l}\text { Papirløse } \\
\text { med fæl- } \\
\text { lesbørn }{ }^{1}\end{array}$ & I alt & & \\
\hline & 1 & 2 & 3 & 4 & 5 & 6 & 7 & & 9 \\
\hline 1 & 1281165 & . & 1281165 & . & . & . & ${ }^{\circ}$ & 1281165 & 1281165 \\
\hline 2 & . & 466664 & 466664 & 103535 & . & . & 103535 & 570199 & 1140398 \\
\hline 3 & . & . & . & 46365 & 216899 & 25116 & 288380 & 288380 & 865140 \\
\hline 4 & . & . & . & 9989 & 290948 & 11267 & 312204 & 312204 & 1248816 \\
\hline 5 & . & . & . & 1753 & 88290 & 1933 & 91976 & 91976 & 459880 \\
\hline $\begin{array}{l}6 \mathrm{og} \\
\text { dero. }\end{array}$ & . & . & . & 418 & 18532 & 439 & 19389 & 19389 & 121065 \\
\hline$I$ alt & 1281165 & 466664 & 1747829 & 162060 & 614669 & 38755 & 815484 & 2563313 & 5116464 \\
\hline
\end{tabular}

1 Antallet er undervurderet.

TRANSLATION. - Heading, Columns 1-3: families without children; 4-7: families with children; 1 and 4: single persons; 2 and 5: married couples; 6: couples living in consensual unions, with joint children; 3 and 7 : total; 8: total number of families; 9: total number of persons. - Front Column: number of persons in the family (1 . . 6 and over); total.

A p p e n d i 2 .

Household types

1 single woman with/without children

1 single man with/without children

1 married couple with/without children

1 couple living in consensual union with joint children

2 single persons of same sex with/without children

2 single persons of opposite sex with/without children

1 married couple with/without children and single persons without children

1 married couple with/without children and 1 single person with children

1 married couple with/without children and single persons with/without children (at least one single person must have children)

1 married couple with/without children and 1 couple living in consensual union with joint children

2 married couples with/without children

2 couples living in consensual union with joint children

3 or more single persons with/without children

Other combinations 
Husstande pr. 1. januar 1983 fordelt efter antal personer

Households at 1 January 1983, by household size

\begin{tabular}{|c|c|c|c|c|c|c|c|c|c|c|}
\hline \multirow{4}{*}{$\begin{array}{l}\text { Antal } \\
\text { perso- } \\
\text { ner i } \\
\text { hus- } \\
\text { stand }\end{array}$} & \multicolumn{8}{|c|}{ Husstande } & \multirow{3}{*}{$\begin{array}{l}\text { Hus- } \\
\text { stande } \\
\text { personer } \\
\text { ialt }\end{array}$} & \multirow{3}{*}{$\begin{array}{c}\text { Antal } \\
\text { personer } \\
\text { i alt }\end{array}$} \\
\hline & \multicolumn{5}{|c|}{ Husstande med en familie } & \multicolumn{3}{|c|}{ Husstande med flere familier } & & \\
\hline & $\begin{array}{l}1 \text { enlig } \\
\text { kvinde } \\
\text { med/ } \\
\text { uden } \\
\text { børn }\end{array}$ & $\begin{array}{l}1 \text { enlig } \\
\text { mand } \\
\text { med/ } \\
\text { uden } \\
\text { børn }\end{array}$ & $\begin{array}{c}1 \\
\text { ægtepar } \\
\text { med/ } \\
\text { uden } \\
\text { børn }\end{array}$ & $\begin{array}{c}1 \\
\text { papirløst } \\
\text { par } \\
\text { med } \\
\text { børn }\end{array}$ & I alt & $\begin{array}{c}2 \text { enl. } \\
\text { af } \\
\text { forsk. } \\
\text { uden } \\
\text { børn }\end{array}$ & $\begin{array}{l}\text { Hus- } \\
\text { stande } \\
\text { i øvrigt }\end{array}$ & I alt & & \\
\hline & 1 & 2 & 3 & 4 & 5 & 6 & 7 & 8 & 9 & 10 \\
\hline 1 & 386498 & 258849 & . & & 645347 & . & . & . & 645347 & 645347 \\
\hline 2 & 53382 & 11636 & 423659 & . & 488677 & $143 \quad 192$ & 33908 & 177100 & 665777 & 1331554 \\
\hline 3 & 28738 & 3582 & 200762 & 22710 & 255792 & 23462 & 50594 & 74056 & 329848 & 989544 \\
\hline 4 & 6778 & 686 & $276 \quad 277$ & 10311 & 294052 & 10873 & 25081 & 35954 & 330006 & 1320024 \\
\hline 5 & 1244 & 115 & 82674 & 1783 & 85816 & 2647 & 17892 & 20539 & 106355 & 531775 \\
\hline $6 \underset{\text { dero. }}{\mathrm{og}}$ & 305 & 23 & 16890 & 402 & 17620 & 712 & 18357 & 19069 & 36689 & 298220 \\
\hline$I$ alt & 476945 & 274891 & 1000262 & 35206 & 1787304 & 180886 & 145832 & 326718 & 2114022 & 5116464 \\
\hline
\end{tabular}

TRANSLATION. - Heading, Columns 1-5: households comprising only one family; $6-8$ : households comprising more than one family; 1 : a single woman with/without children; 2 : a single man with/without children; 3 : a married couple with/without children; 4 : a couple living in consensual union, with children; $5:$ total; 6: two single persons of opposite sex with/without children; 7: other households; 8: total; 9: total number of households; 10: total number of persons. - Front column: number of persons in household (1 .6 and over); total.

A p pendix 3 .

Actual and legal duration of marriage 1970 and 1982

\begin{tabular}{llllll}
\hline $\begin{array}{l}\text { Duration of } \\
\text { marriage in } \\
\text { years }\end{array}$ & \multicolumn{2}{c}{1970} & & & 1982 \\
\cline { 2 - 3 } \cline { 2 - 5 } & Legal & Actual & & Legal & Actual \\
\hline
\end{tabular}

\begin{tabular}{rrrrr}
$0-4$ & 30 & 39 & 28 & 37 \\
$5-9$ & 31 & 24 & 25 & 22 \\
$10-14$ & 14 & 13 & 18 & 16 \\
$15-19$ & 10 & 9 & 14 & 13 \\
$20-24$ & 8 & 12 & 8 & 7 \\
$25+$ & 8 & 3 & 7 & 5 \\
\hline Total & 101 & 100 & 100 & 100 \\
\hline
\end{tabular}

1) From the survey of divorces and separations, 1971. A random sample survey based on just under 3.400 divorces. 
Divorces 1982 by number of children at date when marriage was dissolved

\begin{tabular}{|c|c|c|c|c|c|}
\hline \multirow[t]{2}{*}{$\begin{array}{l}\text { Number of } \\
\text { children }\end{array}$} & \multirow[t]{2}{*}{$\begin{array}{l}\text { Without } \\
\text { children }\end{array}$} & \multicolumn{3}{|c|}{$\begin{array}{l}\text { With children } \\
\text { (Age of eldest child) }\end{array}$} & \multirow[b]{2}{*}{ Total } \\
\hline & & $0-6$ years & $7-14$ years & $15-17$ years & \\
\hline 0 & 3128 & & $x^{2}$ & & 3128 \\
\hline 1 & & 2151 & 1088 & 647 & 3886 \\
\hline 2 & & 1294 & 2177 & 958 & 4429 \\
\hline 3 & & 88 & 732 & 463 & 1283 \\
\hline 4 & 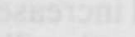 & 5 & 127 & 105 & 237 \\
\hline $5+$ & & & 27 & 38 & 65 \\
\hline Total & 3128 & 3538 & 4151 & 2211 & 13028 \\
\hline
\end{tabular}

Divorces 1982 by actual duration of marriage

\begin{tabular}{|c|c|c|c|c|c|}
\hline \multirow{2}{*}{$\begin{array}{l}\text { Duration of } \\
\text { marriage } \\
\text { in years }\end{array}$} & \multicolumn{2}{|c|}{ No children } & \multicolumn{2}{|c|}{ With children } & \multirow[b]{2}{*}{ Total } \\
\hline & Number & $\%$ & Number & $\%$ & \\
\hline $0-4$ & 1491 & 47.6 & 3287 & 33.2 & 4778 \\
\hline $5-9$ & 441 & 14.1 & 2383 & 24.1 & 2824 \\
\hline $10-14$ & 221 & 7.1 & 1899 & 19.2 & 2120 \\
\hline $15-19$ & 141 & 4.5 & 1531 & 15.5 & 1672 \\
\hline $20-24$ & 269 & 8.6 & 606 & 6.1 & 875 \\
\hline $25+$ & 520 & 16.6 & 157 & 1.6 & 677 \\
\hline Not stated & 45 & 1.4 & 37 & 0.4 & 82 \\
\hline Total & 3128 & 100 & 9900 & 100 & 13028 \\
\hline
\end{tabular}

\section{References}

Jensen, Poul. (1983). Towards a register-based statistical system - some Danish Experience. Statistical Journal 1 (3): 341-365.

Noordhoek, J. A. and Petersen, O. K. (1984). Household and family concepts in Danish population registers and surveys. Statistical Journal 2 (2): 169-178.

The Person-Number Systems of Sweden, Norway, Denmark and Israel. (1984). Vital and Health Statistics Series 2, 84. 